\title{
OPĆEPOZNATE ČINJENICE U PARNIČNOM POSTUPKU
}

Dr. sc. Mihajlo Dika, professor emeritus

Pravni fakultet Sveučilišta u Zagrebu
UDK: $347.91 / .95$

Ur.: 15. veljače 2017 .

Pr.: 21. veljače 2017 .

Izvorni znanstveni rad

\section{Sažetak}

U radu se nastoji sustavno i cjelovito obraditi institut općepoznatih činjenica $u$ hrvatskom parničnom pravu, s osvrtom na neke stavove koji su o tome isntitutu zauzeti u bivšoj jugoslavenskoj i postjugoslavenskoj te austrijskoj i njemačkoj doktrini i judikaturi. Prva je polazna teorijska osnova istraživanja stav da je utvrđivanje činjenica primjenom pravila o općepoznatim činjenicama jedna od metoda utvrđivanja činjenica, metoda u koje pripadaju i dokazivanje kao redovna, ali ipak (u pravilu) supsidijarna metoda, te utvrđivanje činjenica primjenom pravila o priznanju činjenica, o pravnim presumpcijama i o teretu dokazivanja. Druga je polazna teorijska osnova stav da je pravo utvrđivanja činjenica koje uređuje sve navedene metode dvojako po svojoj pravnoj prirodi: utvrđujući kriterije za formiranje zaključka o postojanju činjenica, to pravo uređuje sadržajnu, pravozaštitnu dimenziju metoda o kojima je riječ, metoda primjenom kojih se utvrđuje sadržaj niže premise logičkog silogizma presude (pravozaštitno pravo utvrđivanja činjenica); propisujući proceduru po kojoj se postupa prigodom formiranja tih zaključaka, ono uređuje njihovu formalnu, procesnopravnu dimenziju (procesno pravo utvrđivanja činjenica). U samom se radu problematiziraju pojam, zakonske osnove $i$ bitne odrednice instituta notornosti te modaliteti njegove postupovne operacionalizacije; pledira se za usko tumačenje pojma u smislu da notornost pretpostavlja i znanje suda o takvom svojstvu neke činjenice, zbog čega se zauzima i negativan stav prema mogućnosti dokazivanja notornosti (sucu nametnuta notornost); ratio instituta pronalazi se u razlozima procesne ekonomije i ekspeditivnosti, ali se upozorava i na mogućnost njegove zlouporabe u praksi; naglašava se potreba razlikovanja negativnog aspekta instituta ( $z$ zabrana» dokazivanja općepoznatih činjenica») $i$ njegovog pozitivnog aspekta (dužnost da se uzme da činjenica postoji onako kako je to općepoznato); iznosi se i nastoji argumentirati da je sigurnost zahtijevana razina uvjerenosti u notornost te da je sumnja u notornost neke činjenice dovoljan razloga da se radi njezinog utvrđivanja primijene druge metode koje su tome namijenjene, u pravilu dokazivanje; izlaže se struktura prigovora nenotornosti $i$ procedura koja se u povodu takvog prigovora treba provesti; argumentira se stav o dužnosti suda da po službenoj dužnosti uzima u obzir općepoznate činjenice; objašnjava se u čemu se sastoji zabrana dokazivanja koja se veže uz takve činjenice; ističe se dužnost suda da stranke upozna sa svojim stavom o 
notornosti nekih činjenica $i$ da im omogućiti da o tome raspravljaju; razmatraju se pravne posljedice povrede pravila o notornosti te mogućnost da se zbog takvih povreda podnose određeni pravni lijekovi; ispituje se odnos utvrđivanja činjenica po pravilima o notornosti s drugim metodama njihova utvrdivanja, pri čemu se konstatira da mogućnost formiranja zaključka o postojanju nekih činjenica po pravilima o neoborivim predmnjevama ima funkcionalnu prednost pred notornošću. Polazeći od stava koji je zauzet o pravnoj prirodi instituta notornosti, ali i od načina na koji je uređen u zakonu, zauzima se stav da je za prosuđivanje tog instituta uvijek mjerodavno pravo suda. Zaključno se rekapituliraju bitni rezultati provedene analize instituta.

\section{Ključne riječi: općepoznate činjenice, utvrđivanje činjenica, parnični postupak.}

\section{UVOD}

Zakon o parničnom postupku' ${ }^{1}$ (Zakon, ZPP) uređuje, između ostaloga, i pojedine metode utvrđivanja činjenica. Centralno mjesto u sustavu tih metoda ima dokazivanje. Međutim, dokazivanje je, ipak, osim ako nije riječ o kvalificiranim dokazima (v. infra ad III.11.), metoda koja se suspidijarno primjenjuje - onda kad se zaključak o postojanju neke činjenice ne uspije formirati na zahtijevanoj razini utvrđenosti ${ }^{2}$ po pravilima o općepoznatim činjenicama (221/4.; v. infra ad II.1.), ${ }^{3}$ po pravilima o priznanju činjenica $(221 / 1 ., 2 \text {. })^{4}$ i po pravilima o zakonskim predmnjevama $(221 / 3$. $){ }^{5}$ Bilo bi riječi o nekim od nedokaznih metoda utvrđivanja činjenica, u koje pripadaju, ali kao dokazivanju supsidijarne metode utvrđivanja, još i zaključivanje o činjenicama po pravilima o tzv. slobodnoj ocjeni $(223 ., 223 . a)^{6}$ te po pravilima o

1 NN, proč. 25/13. i 89/14.

$2 \mathrm{O}$ problemu zahtijevane razine utvrđenosti činjenica u parničnom postupku usp. DIKA, O standardima utvrđenosti činjenica u parničnom postupku, ZBO PF RI 1/2015.

3 U ovom radu odredbe pojedinih zakona označavat će se navođenjem broja članka, stavka odvojenog kosom crtom od broja članka, te točke ili rečenice u istom stavku, odvojene točkom od broja članka ili stavka. Više će stavaka ili točaka istog članka ili stavka međusobno biti razdvojeno zarezom. Crtica između brojeva dvaju članaka ili stavaka koristit će se radi označavanja da se sve odredbe između tih brojeva odnose na tekst ispred njih. Za označavanje pojedinih propisa rabit će se njihove kratice. Jedino će se za označavanje pojedinih odredaba Zakona o parničnom postupku u zagradama navoditi samo njihov broj bez naznake kratice.

4 Ne treba dokazivati činjenice koje je stranka priznala pred sudom tijekom parnice, ali sud može narediti da se dokazuju i takve činjenice ako smatra da stranka njihovim priznanjem ide za tim da raspolaže pravima kojima je može raspolagati (221/1.).

5 Činjenice čije postojanje zakon pretpostavlja ne treba dokazivati, ali se može dokazivati da te činjenice ne postoje, ako zakonom nije što drugo određeno (221/3.). O utvrđivanju činjenica primjenom pravila o pravnim predmnjevama usp. DIKA, Zakonske predmnjeve-prilog učenju o virtualnosti pravne stvarnosti, ZBO PF RI, 1/2014.

6 Prema odredbi članka 223. stavka 1. ZPP-a, ako se utvrdi da stranci pripada pravo na naknadu štete, na novčanu svotu ili na zamjenjive stvari, ali se visina svote odnosno količina stvari ne može utvrditi ili bi se mogla utvrditi samo s nerazmjernim teškoćama, sud će o tome odlučiti prema slobodnoj ocjeni, a prema odredbi članka 223. stavka 2. ZPP-a, ako je potpuno 
teretu dokazivanja (221.a). ${ }^{7}$

Dok je institutima priznanja činjenica i zakonskih (pravnih) predmnjeva $u$ doktrini posvećena bitno veća pažnja, institut općepoznatosti (notornosti) relativno je zanemaren, i to ne samo zato što je vrlo sumarno uređen u Zakonu (v. infra ad II.1.), što uostalom vrijedi i za dva prethodno navedena instituta, već stoga što u praksi nije izazivao neke posebne probleme. Praktična je važnost instituta, međutim, bitno veća nego što se obično misli. Općepoznate činjenice, doduše, rijetko imaju značenje neposredno relevantnih činjenica. Njihova se prava važnost može spoznati tek ako se uzme uobzir uloga koje one imaju kao indiciji. Dovoljno je u tom smislu upozoriti na realitet da činjenice koje tvore objekte „općepoznatih“ pravila iskustva također imaju značenje općepoznatih činjenica, činjenica znanje o kojima nam se čini tako prirodnim i samorazumljivim da o njima ne vodimo posebno računa. Između ostaloga takve činjenice svoju nezamjenjivu ulogu imaju prigodom formiranja tzv. slobodne ocjene dokaza.

Bit je pravila o notornosti u tome da ona, s jedne strane, oslobađaju sud dužnosti da općepoznate činjenice utvrđuje dokazivanjem (negativni učinak notornosti), dok, s druge strane, omogućavaju (nalažu) sudu da o takvim činjenicama zauzme stav u skladu s onim što se o njima kao takvima zna (pozitivan učinak notornosti) (v. infra ad II.2.2.3.). Ipak, unatoč tomu što oslobađanjem suda od potrebe da dokazivanjem utvrđuje važne činjenice pridonosi procesnoj ekonomiji i ekspeditivnosti, institut notornosti potencijalno nosi u sebi i određene opasnosti - osobito onda kad se određeno znanje o nečemu smatra (nameće) ne samo kao politički (i ćudoredno) već i kao pravosudno neupitno. ${ }^{8}$ Upravo zato posebnu važnost u primjeni ovog instituta

razjašnjenje okolnosti o kojima ovisi odluka o nekim od više u istoj tužbi istaknutih zahtjeva koji su beznačajni u odnosu prema ukupnom iznosu svih istaknutih zahtjeva povezano s teškoćama koje su nerazmjerne s važnošću tih zahtjeva, sud može o njima odlučiti po slobodnoj ocjeni uzimajući u obzir već razjašnjene okolnosti slučaja i prikupljene dokaze, a osobito isprave koje su stranke priložile te njihove iskaze, ako ih je sud saslušao (članak 264.). Prema odredbi članka 223.a, u sporovima čija vrijednost predmeta spora u postupku pred općinskim sudovima ne prelazi 10.000,00 kuna, a u postupku pred trgovačkim sudovima 50.000,00 kuna sud može, ako ocijeni da bi utvrđivanje činjenica važnih za rješenje spora moglo biti povezano s nerazmjernim teškoćama i troškovima, o postojanju tih činjenica zaključiti po slobodnoj ocjeni uzimajući u obzir isprave koje su stranke priložile te njihove iskaze ako je sud izveo dokaz saslušanjem stranaka (članak 264.).

7 Prema odredbi članka 221.a ZPP-a, ako sud na temelju izvedenih dokaza (članak 8.) ne može sa sigurnošću utvrditi neku činjenicu, o postojanju činjenice zaključit će primjenom pravila o teretu dokazivanja.

8 Neke su ljude i spalili zato što su se usudili tvrditi nešto što se nije podudaralo $s$ onim što se smatralo općeprihvaćenim (i dopuštenim) znanjem - zar ne? Autor se iz vlastite prakse prisjeća jednog slučaja s konca šezdesetih godina prošlog stoljeća u kojemu je osoba koja se za šankom u kafiću usudila ustvrditi da su Sjedinjene Države demokratskije od tadašnje Jugoslavije, bila zbog toga (doduše blago i uvjetno) osuđena zbog kaznenog djela širenja lažnih vijesti i uznemiravanja građana, $i$ to na temelju sumarno provedenog postupka. U tom je postupku jedna od bitnih činjenica (širenje lažnih vijesti da su Sjedinjene Države demokratskije od tadašnje Jugoslavije) bila utvrđena na temelju pravila o notornosti. Sud je, naime, uzeo da je okrivljenik svjesno širio lažne vijesti jer se u tadašnjoj Jugoslaviji moralo smatrati da je općepoznato da je ta država najdemokratskija zemlja na svijetu. 
ima mogućnost dokazivanja da nešto nije općepoznato, odnosno da ne postoji ono ili da ne postoji onako kako je to notorno.

U ovom će se radu nastojati sustavno i cjelovito razmotriti institut općepoznatih činjenica u hrvatskom parničnom pravu, pri čemu će se $-\mathrm{u}$ komparativističkoj perspektivi - problematizirati pojam, zakonske osnove i bitne odrednice toga instituta te modalitete njegove postupovne operacionalizacije. Pokušat će se odrediti i njegov odnos prema institutima koji uređuju druge metode utvrđivanja činjenica, ali i dati odgovor na pitanje o njegovoj pravnoj prirodi te o pravu koje može biti mjerodavno za njegovo prosuđivanje. U tom bi smislu ovaj rad trebao biti shvaćen kao poticaj da se institutu notornosti u doktrini i judikaturi posveti ona pozornost koju zaslužuje.

\section{ZAKONSKE OSNOVE I BITNE ODREDNICE INSTITUTA}

\subsection{Zakonske osnove}

Zakonske osnove instituta postavljene su već spomenutom odredbom članka 221. stavka 4. ZPP-a (v. supra ad I.) prema kojoj ne treba dokazivati činjenice koje su općepoznate. ${ }^{9}$ Dopunski su zakonski izvori instituta odredba prema kojoj će sud u povodu prijedloga za povrat u prijašnje stanje zakazati ročište, osim ako su činjenice na kojima se prijedlog temelji općepoznate (121/2.), zatim odredbe prema kojima je sud prigodom provjere jesu li ispunjeni uvjeti za donošenje presude zbog ogluhe dužan provjeriti nisu li činjenice na kojima se temelji tužbeni zahtjev u protivnosti s činjenicama koje su općepoznte (331.b/1.3.) te ne postoje li općepoznate okolnosti iz kojih proizlazi da su tuženika spriječili opravdani razlozi da podnese odgovor na tužbu (331.b/1.4.), odnosno odredbe prema kojima je sud prigodom provjere jesu li ispunjene pretpostavke za donošenje presude zbog izostanka dužan provjeriti nisu li činjenice na kojima se temelji tužbeni zahtjev u protivnosti s činjenicama koje su općepoznate (332/1.4.) te ne postoje li općepoznate okolnosti iz kojih proizlazi da su tuženika spriječili opravdani razlozi da dođe na ročište $(332 / 1.5$.).

9 U zakonskim uzorima odnosno pretečama ovog propisa institut je notornosti bio unekoliko drukčije postavljen. Tako § 291. dZPO glasi: «Offenkundigkeit. Tatsachen die bei dem Gericht offenkundig sind, bedürfen keines Beweises.», a § 269. öZPO: "Tatsachen, weche bei dem Gericht offenkundig sind, bedürfen keines Beweises.” Slično je propisivao i § 365. ZSPGP 29: «Iznesene činjenice, koje su kod suda opšte poznate, ne treba dokazivati». Odredbe se njemačkog i austrijskog zakona u bitnome tekstualno podudaraju. Međutim, navedena je odredba ZSPGP 29, koja je kao i cijeli zakon bila modelirana prema austrijskom uzoru, koristeći riječi «Iznesene činjenice» umjesto samo «Činjenice» («Tatsachen») otvorila interpretativnu mogućnost da se primjena instituta notornosti ograniči na činjenice koje su stranke iznijele, odnosno mogla je izazvati dilemu je li se prema njoj o općepoznatim činjenicama trebalo voditi računa ex officio neovisno o tome jesu li ih stranke iznijele tijekom postupka ili samo ako su to učinile. 


\subsection{Bitne odrednice instituta}

\subsubsection{O nekim stavovima u doktrini i judikaturi}

\subsubsection{Općenito}

Pojam općepoznatih činjenica u bivšem jugoslavenskom i važećem hrvatskom pravu nije zakonski definiran, a tako nije definiran ni u njemačkom niti autrijskom pravu. ${ }^{10}$ On je zapravo kreacija judikature i doktrine, koje su dosta fluidne i evolutivne u svojim stavovima, sudeći barem prema nekim trendovima u austrijskoj doktrini i judikaturi.

\subsubsection{Onekim stavovima u bivšoj jugoslavenskoj i postjugoslavenskoj doktrini}

U bivšoj jugoslavenskoj doktrini neki su autori, moglo bi se reći, pod utjecajem poimanja instituta formiranog prema rješenjima iz § 365. ZSPGP $29,{ }^{11}$ koja su inače kao pravna pravila važila sve do donošenja jugoslavenskoga Zakona o parničnom postupku iz 1956., razlikovali između opće i sudske notornosti. Pritom su neki autori smatrali da su općepoznate one činjenice koje su znane na većem ili manjem području bilo kakvom velikom mnoštvu ljudi, ako su poznata sudu, kao npr. veliki povijesni i politički događaji, velike katastrofe, poplave, potresi, epidemije itd., dok bi sudski znane bile činjenice za koje je sud saznao iz nekog drugog službenog djelovanja, npr. iz kaznenog postupka, iz zemljišnih knjiga, registara, spisa o drugim predmetima itd. ${ }^{12}$ Drugi su autori općepoznatim smatrali i smatraju činjenice koje su poznate svakom prosječnom čovjeku ili znatnom broju ljudi, u cijeloj zemlji ili u njenim prostranim oblastima, kao npr. «krupan» politički ili elementarni događaj o kojemu piše dnevni tisak, ali i događaji lokalnog značaja, poznati ljudima onog kraja ili mjesta u kome se nalazi sjedište suda, kao npr. prekid autobusnog prometa u određenom trajanju na određenoj dionici puta zbog poplave, veliki požar; slab prinos poljoprivrednih kultura u određenoj godini. Ovi drugi autori, međutim, s tako određenim pojmom notornosti izjednačavaju i činjenice koje su sudu bile poznate iz njegove službene djelatnosti o kojima je stekao znanje u nekom drugom sudskom postupku. ${ }^{13}$

Razlike u stavovima očitovale su se i u tome kome su u sudskom vijeću takve činjenice trebale biti poznate da bi se mogle smatrati općepoznatima. Prema jednima se tražilo da ona bude poznata svim članovima vijeća, ${ }^{14}$ prema drugom se o notornosti odlučivalo većinom glasova. ${ }^{15}$

Općenito se zastupao stav, bez posebne argumentacije, da sud na takve činjenice

10 Za austrijsko i njemačko pravo v. bilj. 6.

11 V. bilj. 6.

12 JUHART, Civilno procesno pravo FLRJ 1961 (cit. JUHART, CPP), 357.

13 POZNIĆ, Borivoje i RAKIĆ-VODINELIĆ, Vesna, Građansko preocesno pravo (cit. POZNIĆRAKIĆ, GPP), 15. izd., 1999., 238., 17. izd., 2015., 381. Takvo se stajalište o notornim činjenicama zastupa od prvog izdanja ovog sustava koji je utemeljio Poznić.

14 POZNIĆ-RAKIĆ, GPP, 15. izd., 238.

15 JUHART, CPP, 357. 
treba paziti po službenoj dužnosti, da nije bilo potrebno da se stranke na njih pozovu. ${ }^{16}$

Iznesena je i teza da sud po slobodnoj ocjeni odlučuje o tomu treba li neku činjenicu smatrati općepoznatom, ${ }^{17}$ odnosno teza da je utvrđenje suda da je neka činjenica notorna činjenično utvrđenje. ${ }^{18}$

\subsubsection{Hrvatska doktrina}

U hrvatskoj građanskoprocesnopravnoj doktrini, koja se u tom pogledu nastavlja na stavove zastupane i s obzirom na prijašnje savezno jugoslavensko uređenje, općepoznate činjenice definiraju se kao činjenice koje su poznate širem krugu ljudi (ne moraju biti poznate svima) u sredini u kojoj se suđenje obavlja (notoria non egent probatione). Pritom se upućuje na sudsku praksu koja je u nekim slučajevima tražila širu notornost stojeći na stajalištu da ne treba dokazivati postojanje samo onih činjenica koje su poznate širem krugu ljudi, dok se u drugim zadovoljavala užom notornošću smatrajući da je dovoljno to što je određena činjenica poznata na užem geografskom području, ili u sredini u kojoj se suđenje obavlja, ${ }^{19}$ ili ljudima određene specijalne profesije pa čak i samom parničnom sudu. ${ }^{20}$

\subsubsection{O nekim stavovima u austrijskoj i njemačkoj doktrini i judikaturi}

U austrijskoj i njemačkoj doktrini i judikaturi razlikuje se između općepoznatih (njem.Allgemeinkundige Tatsachen)i sudskipoznatih činjenica(njem.Gerichtskundige Tatsachen), ${ }^{21}$ za koje razlikovanje ima uporišta i u zakonskom uređenju instituta.

Općepoznatim činjenicama smatraju se činjenice koje su barem na jednom značajnijem (većem ili manjem) području poznate neograničenom mnoštvu ljudi ili se barem bez poteškoća mogu saznati22 i koje su iz tog razloga poznate i sudu. Znanje o njima mora, dakle, na tom području biti općenito prošireno, mnoštvo ljudi mora moći za njih saznati i njihovo postojanje mora za svakoga bez posebne stručnosti iz pouzdanih izvora biti provjerljivo. Među takve bi činjenice pripadala sva nesporna pravila općeg životnog iskustva, općenito poznate povijesne činjenice i događaji, njihove posljedice, osobito za gospodarski život, geografske činjenice, npr.

16 U tom smislu implicite JUHART, CPP, 357., iznoseći stav da se općepoznate činjenice ne moraju navoditi niti dokazivati, a eksplicitno POZNIĆ-RAKIĆ, GPP, 15. izd., 238., a, suprotno tome u 17. izd., 381., uz obrazloženje da to ne bi bilo u skladu s odredbama po kojima sud može uzeti u obzir samo činjenice koje su stranke iznijele (7/1., 2. srb.ZPP 2011).

17 POZNIĆ-RAKIĆ, GPP, 15. izd., 238., 17. izd. 381.

18 JUHART, CPP, 357.

19 VSH: Gž-668/80-PSP-17/146.; VSH: Rev-80/87 - PSP 34/142.

20 Usp. TRIVA-DIKA, Građansko parnično procesno pravo, 2004. (cit. TRIVA-DIKA, GPPP), 487.

21 Genusno ove se dvije kategorije činjenica nazivaju offenkundige (notorische) Tatsachen usp. RECHBERGER-SIMOTTA, Zivilprozessrecht, Erkenntnisverfahren, 7. izd., 2009. (cit. RECHBERGER-SIMOTTA, ZPR), 405.

22 RECHBERGER u FASCHING, Kommentar zu den Zivilprozeßgesetzen, 2. izd., 3. tom., 2004. (cit. RECHBERGER, Fasching. Komm., 3.), 598., poziva se s time u vezi na stav izražen u austrijskoj judikaturi prema kojemu bi trebala biti riječ o činjenicama koje mogu biti poznate svim inteligentnim osobama koje o odnosima njihove sredine (okruženja) vode računa. 
međusobna udaljenost dvaju mjesta, položaj i stanje javnih putova i smještaj zemljišta i zgrada, također dnevni događaji o kojima se javljalo u svim slobodno dostupnim tuzemnim izvorima vijesti. ${ }^{23}$

Prema mišljenju nekih autora, sudski poznate činjenice su činjenice koje su sudu (a ne možda samo sudećem sucu) postale poznate tijekom njegove službene djelatnosti $^{24}$ (neovisno o tomu je li do toga došlo u okviru nekog parničnog postupka ili druge pravosudne ili sudskoupravne djelatnosti; npr., kao službena objava u službenom listu Wiener Zeitung-a). ${ }^{25}{ }^{26}$ Prema shvaćanju drugih, izloženo bi mišljenje imalo za posljedicu da bi značenje sudski poznatih činjenica imale i sve one činjenice za koje bi se moglo saznati iz spisa istoga suda, neovisno o tome na što bi se odnosili. Upravo se stoga prigovara da to mišljenje ide predaleko jer bi u konačnici dovelo do toga da stanovitu činjenicu koja bi jednom u nekom sudu bila utvrđena (za što bi se iz postojećih spisa moglo saznati) ne bi više trebalo dokazivati. Zato se smatra ispravnom novija judikatura prema kojoj sudska poznatost postoji samo onda kad je sucu neka činjenica poznata iz njegove službene djelatnosti, bez potrebe da zbog toga obavi uvide u određene spise, makar se radilo o spisima istoga suda. ${ }^{27}$

$23 \mathrm{U}$ tom smislu ROSENBERG-SCHWAB-GOTTWALD, Zivilprozessrecht, 2010. (cit. ROSENBERG-SCHWAB-GOTTWALD, ZPR), 619., FASCHING, Lehrbuch des österreichischen Zivilprozeßrechts, 1990. (cit. FASCHING, ZPR), 540., RECHBERGERSIMOTTA, ZPR, 405. FASCHING, ZPR, 540., upozorava na oprez kad su u pitanju informacije objavljene u medijima: tisak, radio i film po i za sebe nisu pouzdano provjerljivi izvori jer se svaka u masovnim medijima proširena informacija ne može sadržajno provjeriti. Upravo se stoga ističe da se često kao notorno može uzeti samo to da su te informacije u jednom masovnom mediju proširene i da su time postale općenito poznate, ali ne i da su istinite. Slično i RECHBERGER, Fasching. Komm., 3., 598., koji referira o novijoj austrijskoj judikaturi (538., 539.) koja je, između ostaloga, značenje općepoznatih činjenica priznala okolnostima: da je tijekom posljednjih dvadesetak godina došlo do promjena radne tehnike i načina rada uredskih namještenika, posebno uvođenjem elektroničkih uređaja; da je djelatnost profesionalnog nogometaša posebno izložena riziku, tako da su i onda kad profesionalni invaliditet ne nastupi, tipične profesionalne prenapregnutosti i posljedice povreda mogu dovesti do okončanja profesionalnog sportskog životnog puta prije nastupanja starošću uvjetovane nesposobnosti; da se trafikanti s amputiranim nogama, vezanim uz stolice s kotačima i time isključivo sjedeći, često sreću širom Austrije; - da su u skrbničkim domovima uzete osobe često smještene u krevetima sa zaštitnom ogradom da ne bi mogle ispasti i pritom se povrijediti; da se i kod najmanjih operativnih zahvata, unatoč svih mjerama predostrožnosti, ne može isključiti neka infekcija ili neka time uvjetovana komplikacija; da neka jednoruka osoba može raditi na mnogim, pa i trgovačkim poslovima. S druge strane, zauzet je stav da, između ostaloga, značenje općepoznate činjenice nemaju: predodžba o poslu voditelja filijale velikog trgovačkog lanca (za razliku od one o poslovima portira, prodavača karata itd.) zato što se njegovo stručno obrazovanje ne odvija pred očima javnosti; okolnost da se na nekim sveučilištima odnosno fakultetima zbog općih uvjeta studiranja pogoršalo dovršenje studija; činjenice čije opažanje pretpostavlja posebno obrazovanje, iskustvo ili djelatnost; posebnosti nekog lokaliteta koje može spoznati samo netko tko raspolaže posebnim poznavanjem nekog mjesta ili sličnim sposobnostima.

24 Usp.: FASCHING, ZPR, 450.; ROSENBERG-SCHWAB-GOTTWALD, ZPR, 629.

25 FASCHING, ZPR, 450.; ROSENBERG-SCHWAB-GOTTWALD, ZPR, 629.

26 ROSENBERG-SCHWAB-GOTTWALD, ZPR, 630., ističu s time u vezi da puko iz drugih spisa pribavljivo znanje ne bi dostajalo: sudac bi, štoviše, već morao znati za činjenicu.

27 RECHBERGER, Fasching.Komm., 3., 599., 600., koji, ipak, smatra da bi mogli biti sporni 
Inzistira se na potrebi oštrog razlikovanja između sudski poznatih činjenica i privatnog znanja suca, u okviru kojega treba razlikovati njegovo znanje kao svjedoka i kao vještaka. ${ }^{28}$

Budući da su sudski notorne činjenice nerijetko nepoznate jednoj ili objema strankama, sud bi ih morao, osobito onda kad su stranački navodi s tim činjenicama u protivnosti ili se čini da strankama nisu poznate objektivno postojeće općepoznatne činjenice, u granicama materijalnog upravljanja parnicom, s njima raspraviti ako ih hoće uzeti u obzir po službenoj dužnosti u slučaju u kojemu ih niti jedna od njih nije iznijela - to bi zahtijevalo pravo na pravno saslušanje. ${ }^{29}$ To bi trebalo učiniti i kad notornost neke činjenice ne bi bila potpuno izvan sumnje. Povreda ovih obveza može biti povredom postupka. ${ }^{30}$

Općepoznate (notorne) činjenice ne treba dokazivati; one ne moraju biti ustvrđene, već ih je sud dužan po službenoj dužnosti postaviti kao osnovu svoje odluke. Općepoznate činjenice obuhvaćene su dužnošću stranaka da iznose istinito i potpuno činjenično stanje. One nisu predmet priznanja; njima protuslovno priznanje je bez učinka, jednako kao što njihovo osporavanje ne može spriječiti da budu vrednovane kao općepoznate činjenice. U parnici pred vijećem većina članova vijeća određuje je li nešto općepoznato. Dopušteno je dokazivati da nije točno da je neka činjenica općepoznata. Bio bi dopušten i protudokaz da ne postoji činjenica koja se smatra općepoznatom. O općepoznatosti odlučuje sud s obzirom na svoju instanciju. Utvrđenje da je neka činjenica općepoznata može se pobijati kao nepravilno utvrđenje činjenice. ${ }^{31}$ Može se dokazivati općepoznatost za koju sud ne zna. ${ }^{32}$

konkretni slučajevi na temelju kojih su ova načela razvijena. Tako on prigovora stavovima u novijoj judikaturi, koja se glede toga distancira od prijašnje prakse prema kojoj su se sudski poznatima smatrale činjenice unijete u zemljišne knjige i registar tvrtki, koja takvim činjenicama negira takvo svojstvo, obrazlažući svoju unesene okolnošću da danas činjenice unesene u javne registre svatko može pribaviti zahvaljujući mogućnostima moderne informacijske tehonologije, ali i time da i ROSENBERG-SCHWAB-GOTTWALD, ZPR, § 111., Rz 29., smatraju da su unosi u javne register sudski poznati. Suglašava se, međutim, sa stavom judikature da se u službenom glasilu objavljeno dopuštenje nekog lijeka ne smatra sudski poznatim kad ono sucu nije činjenično poznato.

28 Usp.: FASCHING, ZPR, 451.; RECHBERGER, Fasching.Komm., 3., 600., 601.; RECHBERGER-SIMOTTA, ZPR, 405.

29 U tom smislu ROSENBERG-SCHWAB-GOTTWALD, ZPR, 17. izd., 629., naglašavaju da treba prije vrednovanja jedne takve činjenice osigurati pravo na pravno saslušanje.

30 Usp.: FASCHING, ZPR, 450.; RECHBERGER, Fasching. Komm., 3., 601.

31 Usp.: FASCHING, ZPR, 450., 452.; RECHBERGER, Fasching. Komm., 3., 601.; ROSENBERG-SCHWAB-GOTTWALD, ZPR, 17. izd., 630.

32 ROSENBERG-SCHWAB-GOTTWALD, ZPR, 17. izd., 630. Takvo bi se dokazivanje provodilo u pravilu svjedocima, a vještacima samo tamo gdje bi ono počivalo na znanstvenom uvjerenju, kao npr. kod neopaženih povijesnih ili geografskih pitanja, kod konkurentskih parnica ispitivanjem mišljenja, i imalo bi značenje indicijskog dokaza o istinitosti navodno općepoznate činjenice. Dokazivanje sudske poznatosti ne bi bio dopušten. 


\subsubsection{Vlastiti stav}

\subsubsection{Određenje pojma}

Pojam općepoznatih činjenica nije zakonski definiran. Riječ je zapravo o jednom relativno neodređeno postavljenom pravnom standardu čiji se konkretniji sadržaj treba kazuistički razraditi. Pritom bi, s jedne strane, trebalo voditi računa o razlozima procesne ekonomije i ekspeditivnosti koji determiniraju njegovu pravozaštitnu svrhu (v. infra ad 2.2.2.), a, s druge strane, uzeti u obzir i moguće opasnosti koje bi njegova «preslobodna» primjena involvirala. Neovisno o rečenom, relativno stroži zahtjevi u određivanju tog pravnog standarda i time uvjetovano uže utvrđenje njegova značenja mogli bi se opravdati i načelnim stavom da iznimne situacije, one u kojima se odstupa od redovnih bitno određenije uređenih metoda utvrđivanja činjenica poput dokazivanja, primjena kojih upravo zbog toga jamči pravilnu i zakonitu odluku, treba usko tumačiti. Naime, uz notornost se veže zabrana dokazivanja kao redovne (iako u pravilu supsidijarne) metode utvrđivanja činjenica, na što doslovno upućuje dikcija odredbe članka 221. stavka 4. ZPP-a; ona, pored toga, isključuje i primjenu pravila o priznanju činjenica, ali i primjenu pravila o oborivim pravnim predmnjevama (v. infra ad III.11.). Upravo bi stoga «olaka» ili «programirana» primjena instituta i u slučajevima u kojima to ne bi bilo «objektivno» opravdano mogla dovesti do uskrate prava na pravično suđenje.

Uzimajući u obzir rečeno, općepoznatim treba smatrati činjenice koje su (mogu biti) barem na određenom - većem ili manjem - području poznate (skoro) svim razumnim ljudima standardnog obrazovanja, informiranosti i sposobnosti koji na njemu žive ili djeluju i koje su upravo zato i kao takve poznate i sucu (sucima) koji rješava (rješavaju) konkretni predmet.

Notornost, dakle, pretpostavlja: (1) da sudac zna za određenu činjenicu i (2) da ono što o njoj zna, zna zato što je to općepoznato, da, dakle, zna da je činjenica koju zna općepoznata. Sučevo znanje o nečemu što nije i općepoznato jest njegovo privatno znanje - znanje svjedoka ili vještaka i za to znanje ne vrijede pravila o notornosti, već pravila o privatnom znanju suca, ili eventualno o njegovu znanju koje je stekao u svom radu kao sudac.

Zato što notornost pretpostavlja da sud zna za određenu činjenicu jer je općepoznata, prigodom suđenja u vijeću ona treba biti poznata svim članovima vijećatu ne smije biti preglasavanja. Naime, ako neka činjenica nije poznata svim članovima vijeća, nije općepoznata, svakako, osim ako se određenje pojma ne "omekša" prihvaćanjem kriterija "pretežnije" ili "značajnije" poznatosti. Preglasavanje bi, evetualno, bilo moguće samo o tome je li neka činjenica za koju znaju svi članovi vijeća općepoznata.

Stajalište zastupano u austrijskoj doktrini (v. supra ad 2.1.4.) po kojemu pojam notornosti obuhvaća i činjenice koje se moglu bez poteškoća saznati i znanje o kojima se bez posebne stručnosti može iz pouzdanih izvora provjeriti ne čini se prihvatljivim - ono u pojam notornosti uključuje i činjenice za koje sud koji sudi ne zna, ali ih može saznati. Takvo stajalište implicira dužnost suda da ex offcio provodi odgovarajuće provjere, što bi bilo u protivnosti s raspravno organiziranim parničnim 
postupkom. Naime, prema važećem hrvatskom uređenju parničnog postupka, sud više nije dužan (ex officio) istinito i potpuno utvrditi činjenično stanje, kako je to, uz određene relativizacije, bio dužan do Novele 2003. (usp. prij. 7/1.), što se inače s aspekta austrijskog prava, u kojemu takva odredba (i dalje) postoji, ističe kao jedan od argumenata u prilog stavu o dužnosti suca da prigodom donošenja svoje odluke uzme u obzir i činjenice iz drugih sudskih spisa i javnih evidencija. ${ }^{33}$ Upravo bi stoga, u granicama dominantnog raspravnog načela koje vrijedi kako u odnosu na činjenice tako i u odnosu na dokaze (arg. ex 7/1., 2.), inzistiranje na stavu da se notornima smatraju i činjenice koje se bez poteškoća mogu saznati i znanje o kojima se bez posebne stručnosti i poteškoća može provjeriti bilo u protivnosti s tim uređenjem i nametalo bi sucu dužnost da ex officio traga za takvim činjenicama, pri čemu bi propust suda da uzime u obzir i takve činjenice imao za posljedicu nepotpuno utvrđenje činjeničnog stanja. Situacija bi dodatno postala bitno složenijom ako bi se prihvatio i stav da bi sud, vodeći računa po službenoj dužnosti i o tzv. sudski poznatim činjenicama, morao uzeti u obzir i činjenice o kojima bi se podatci mogli pribaviti iz spisa toga suda, odnosno iz javnih evidencija.

S aspekta hrvatskoga prava nema mjesta ni razlikovanju između općepoznatih i sudski poznatih činjenica. To pravo, naime, ne poznaje institut sudski poznatih činjenica niti daje osnove da se on impostira; ono govori samo o općepoznatim činjenicama (v. supra ad 1.). Stavovi u bivšoj jugoslavenskoj i postjugoslavenskoj doktrini o sudski poznatim činjenicama mogu se smatrati posljedicom doktrinarne inercije koja je i s aspekta uređenja inauguriranog Zakonom iz 1956. i potvrđenog Zakonom iz 1976. zastupala rješenja koja su svoje utemeljenje imale u ZSPGP-a iz 1929., odnosno u još ranijem öZPO-u iz 1895., propisnicima koji su razlikovali odnosno razlikuju te dvije kategorije činjenica.

\subsubsection{Ratio}

Ratio instituta notornosti treba tražiti, kako je to već supra (ad I. i 2.2.1.) nagoviješteno, u razlozima procesne ekonomije i ekspeditivnosti. Dokazivati ono što je općepoznato, značilo bi dokazivanjem doći do znanja koje se već posjeduje o nečemu zbog posebnog svojstva tog nečeg. Takvo je dokazivanje nepotrebno jer ne može dovesti do drukčijeg utvrđenja o onome što je zahvaljujući svojoj notornosti već poznato i tako utvrđeno.

\subsubsection{Struktura pravila o notornosti}

Opća (i osnovna) odredba o općepoznatim činjenicama (221/4.), time što propisuje da ne treba dokazivati činjenice koje su općepoznate, izričito eksplicira samo negativno pravilo o tim činjenicama, pravilo koje propisuje što se s njima ne treba raditi, pravilo koje zapravo zabranjuje njihovo dokazivanje. Ono, međutim, ne daje izravan odgovor na pitanje kako će i kakav zaključak o postojanju neke činjenice smijeti (i biti dužan) formirati sud kad nađe da je općepoznata. Odgovor na to pitanje daje jedno drugo, pozitivno, pravilo - pravilo koje je implicirano u navedenom

33 V. bilj. 24. i tekst izrada te bilj. 
ekplicitnom (negativnom) pravilu, pravilo da se za općepoznate činjenice, zato što su takve, smatra da postoje onako kako su općepoznate i da je sud dužan na takvom svom znanju o njima utemeljiti svoju odluku, svakako, osim ako se ne utvrdi da nisu općepoznate ili da - unatoč svojoj notornosti - ne postoje ili da nisu onakve kako je općepoznato. Tek s ovim drugim pravilom institut notornosti dobiva svoj puni, pravi smisao kao institut koji uređuje jednu od metoda formiranja zaključka o postojanju činjenica, jednu od metoda utvrđivanja činjenica.

$\mathrm{Na}$ postojanje navedenog pozitivnog pravila, osim logike instituta koja se može izvesti iz Zakonom izrijekom utvrđenog negativnog pravila, upućuju i već citirane odredbe prema kojima je sud prigodom provjere jesu li ispunjeni uvjeti za donošenje presude zbog ogluhe dužan provjeriti nisu li činjenice na kojima se temelji tužbeni zahtjev u protivnosti s činjenicama koje su općepoznate (331.b/1.3.), te ne postoje li općepoznate okolnosti iz kojih proizlazi da su tuženika spriječili opravdani razlozi da podnese odgovor na tužbu (331.b/1.4.), zatim, odredbe prema kojima je sud prigodom provjere jesu li ispunjene pretpostavke za donošenje presude zbog izostanka dužan provjeriti nisu li činjenice na kojima se temelji tužbeni zahtjev u protivnosti s činjenicama koje su općepoznate (332/1.4.) te ne postoje li općepoznate okolnosti iz kojih proizlazi da su tuženika spriječili opravdani razlozi da dođe na ročište (332/1.5.) - odredbe koje polaze od toga da neka općepoznata činjenica postoji onako kako je to za nju općepoznato i da je kao takvu treba uzeti u obzir prigodom donošenja odluke. Isto značenje kao i navedene odredbe ima i odredba prema kojoj će sud u povodu prijedloga za povrat u prijašnje stanje zakazati ročište, osim ako su činjenice na kojima se prijedlog temelji općepoznate (121/2.).

\subsubsection{Presumptivnost pravila o općepoznatim činjenicama}

Pravila o utvrđivanju općepoznatih činjenica zapravo su specifična presumptivna pravila, pravila koja uz utvrđenje da je nešto općepoznato (presumptivna baza) nalažu zaključak da to i postoji onako kako je to općepoznato (presumirana činjenica). Budući da je riječ o oborivoj predmnjevi, dopušteno je dokazivati da nešto nije općepoznato (napad na presumptivnu bazu protudokazom), ali i da ono što je općepoznato ne postoji ili da nije onako kako je općepoznato (dokaz o protivnom). Pritom je dokazom o protivnom dovoljno samo dovesti u pitanje pouzdanost znanja o postojanju onog što je općepoznato. U tom je smislu na protivniku teret dokazivanja da postoje razlozi za sumnju u postojanje te tako presumirane činjenice. V. infra ad III.3.

\subsubsection{Pravna priroda i mjerodavno pravo}

Pravila koja uređuju utvrđivanje činjenica primjenom pravila o notornosti tiču se načina formiranja i sadržaja zaključka o njihovu postojanju na temelju jednog njihovog specifičnog svojstva, i kao takva mogu imati procesnopravno (formalno) i pravozaštitno (sadržajno) značenje. Kao pravila primjenom kojih će se formirati zaključak o postojanju ili nepostojanju činjenice koju treba utvrditi, ta pravila pripadaju kategoriji ,pravozaštitnog prava utvrđivanja činjenica“, prava koje uređuje sadržajni aspekt utvrđivanja činjenica kao elementa niže premise logičkog silogizma presude. 
S druge strane, pravila koja uređuju postupanje suda prigodom utvrđivanja činjenica primjenom pravila o općepoznatim činjenicama pripadaju kategoriji ,procesnog prava utvrđivanja činjenica“, prava koje uređuje postupak utvrđivanja činjenica primjenom različitih metoda utvrđivanja činjenica. U tom je smislu pravilo po kojemu se smatra da općepoznata činjenica postoji onako kako je to o njoj općepoznato pravilo „pravozaštitnog prava utvrđivanja činjenica“, dok je pravilo po kojemu je sud koji smatra da je neka činjenica općepoznata dužan o tome obavijestiti stranke i omogućiti im da se o tome izjasne - pravilo ,procesnog prava utvrđivanja činjenica“.

Za utvrđivanje činjenica primjenom pravila o općepoznatim činjenicama bit će uvijek mjerodavno pravo suda, i to stoga što ta pravila nemaju nikakvih izravnih, ali ni posrednih dodirnih poveznica s mjerodavnim materijalnim pravom, za razliku, npr., od pravila o pravnim predmnjevama i o teretu dokazivanja te, eventualom, pravila o dokazivanju. Pravo suda bit će mjerodavno i za određivanje sadržaja i opsega samog pojma instituta, ali i za određivanje pretpostavaka i učinaka njegove primjene.

\section{UTVR円IVANJE ČINJENICA PO PRAVILIMA O OPĆEPOZNATIM ČINJENICAMA}

\subsection{Općenito}

Utvrđivanje činjenica po pravilima o općepoznatim činjenicama jest jedna od metoda njihova utvrđivanja - pored dokazivanja, ali i pored utvrđivanja činjenica po privilima o njihovu priznanju (221/1., 2.), po pravilima o pravnim predmnjevama (221/3.), po pravilima o slobodnoj ocjeni $(223 ., 223 . a)$ te po pravilima o teretu dokazivanja (221.a) (v. i infra ad III.11.).

\subsection{Potrebna razina uvjerenosti u notornost}

Sudac neku činjenicu smije smatrati općepoznatom i uzeti da postoji onako kako je to notorno samo ako je siguran da je ona općepoznata te da postoji onako kako je to notorno. Čim posumnja u to da je notorna ili da postoji, odnosno da ne postoji onako kako je notorno, dužan ju je utvrđivati drugim (raspoloživim) metodama. Na takav zaključak upućuje i dikcija odredbe članka 221. stavka 4. ZPP-a prema kojoj općepoznate činjenice ne treba dokazivati, što nužno implicira uvjerenost suca $u$ postojanje određene činjenice kao općepoznate, a ne možda u (pretežniju) vjerojatnost ili mogućnost njezina postojanja kao takve. ${ }^{34}$

\subsection{Obaranje notornosti}

Budući da sud treba biti siguran u notornost neke činjenice, dovoljno je da protivnik stranke za koju je povoljno postojanje navodno notorne činjenice

34 Zahtjev potrebne razine uvjerenosti u notornost neke činjenice bilo bi, eventualno, moguće sniziti na vjerojatnost onda kad bi bila dovoljna ta razina utvrđenosti neke činjenične pretpostavke. 
protudokazom dovede u pitanje sigurnost uvjerenja u njezinu notornost pa da sud pristupi provjeri njezina postojanja primjenom drugih raspoloživih metoda utvrđivanja činjenica, u pravilu dokazivanjem. U tom je smislu u načelu dopušteno tvrditi i dokazivati da činjenica nije notorna, odnosno da, unatoč tome što je notorno da postoji, ipak ne postoji ${ }^{35}$ ili da ne postoji onako kako je notorno.

Izjašnjavajući se o stavu suda o notornosti neke činjenice, stranke bi, dakle, mogle: (1) tvrditi i dokazivati da ona nije općepoznata (što bi impliciralo i tvrdnju da ne postoji ili da ne postoji onako kako se - pogrešno smatrajući da je notorna - misli) te da zato primjenom drugih raspoloživih metoda utvrđivanja činjenica treba provjeriti njezino postojanje, a, zatim, (2) ako nije sporna njezina notornost, tvrditi i dokazivati da ne postoji ili da, ako postoji, postoji drukčije od onoga što je o njoj općepoznato. Tvrditi drukčije značilo bi tvrditi da je "istina" djelomično ili u izmijenjenom smislu različita od onoga što sud smatra da je općepoznato, odnosno da sadržaj onoga što je notorno treba drukčije razumjeti (problem "interpretacije" onoga što je općepoznato).

\subsection{Postupanje suda u povodu prigovora nenotornosti}

Sud se u povodu tvrdnji da neka činjenica nije notorna ili da ne postoji ili da ne postoji onako kako je to notorno treba upustiti u dokazivanje (provjeru) njihove opravdanosti (osnovanosti) samo ako ocijeni da su one relevantne, da će, ako se pokaže da su točne, biti dovedena u pitanje notornost znanja o nekoj činjenici. Upravo će stoga stav suda o tome treba li se upustiti u provjeru notornosti ili postojanja neke činjenice najprije ovisiti o hipotetskoj konkluzivnosti tvrdnji kojima se dovode u pitanje takva njezina svojstva, a zatim i o tome jesu li one potkrijepljene i kakvim dokazima. Sud, svakako, treba voditi računa i o svojoj dužnosti da postupak provede bez odugovlačenja, u razumnom roku, sa što manje troškova te da onemogući svaku zloupotrebu prava u postupku (10/1.).

O sucu, dakle, ovisi hoće li dopustiti utvrđivanje (uključujući i dokazivanjem) da neka činjenica nije notorna, odnosno da ne postoji ili da ne postoji onako kako je notorno da postoji, jednako kao što o njemu ovisi hoće li radi toga uopće dopustiti izvođenje dokaza te, ako ga dopusti, kojih dokaza ( $\arg$. ex 292.). Prije donošenja odluke, strankama treba omogućiti da se o tome izjasne (7/3; v. infra ad III.9.).

Sud ne bi samo po slobodnoj ocjeni, kako se to u doktrini tvrdi (v. supra ad II.2.1.2.), odlučivao o tome treba li neku činjenicu smatrati općepoznatom. ${ }^{36} \mathrm{Ako}$ bi do svog stava o neosnovanosti prigovora nenotornosti došao uzimajući u obzir samo nekonkluzivnost navoda kojima je on potkrijepljen, tada bi bila riječ o standardnom hipotetskom logičkom zaključku. Ako bi radi provjere izveo i neke dokaze, tada bi o vrsti dokaza ovisila metoda primjenom koje bi ih vrednovao. Tako, ako bi se protivno dokazivalo pravomoćnom sudskom odlukom, u granicama njezine pravomoćnosti u kojima ima snagu neoborive predmnjeve, sud svoj stav o protivnom ne bi nikako mogao formirati po slobodnoj ocjeni - on bi o protivnom morao zaključiti na temelju zakonskih odredaba koje bi mu to nalagale. Isto bi vrijedilo i kad bi na zaključak

35 Usp. TRIVA-DIKA, GPPP, 487., 488.

36 POZNIĆ-RAKIĆ, GPP, 15. izd., 238., 17. izd., 381., v. supra ad II. 2.1.2. 
o protivnom ili drukčijem upućivale neke druge neoborive predmnjeve (v. infra ad III.11.). On bi do svog stava o utemeljenosti prigovora nenotornosti ili o protivnom mogao doći na temelju slobodne ocjene dokaza koje bi izveo tek ako za vrednovanje njihove dokazne snage ne bi bila mjerodavna pravila o tzv. formalnoj ocjeni dokaza. Sud bi po slobodnoj ocjeni (koja ne bi bila slobodna ocjena dokaza [8.], već možda ocjena koja bi bila bliža onoj po kojoj bi sud vrednovao okolnost da stranka kojoj je to naloženo nije predujmila sredstva za izvođenje nekog dokaza [153/3.], odnosno onoj po kojoj vrednuje okolnost da je stranka uskratila davanje svog iskaza [269/2.]) odlučivao o opravdanosti prigovora nenotornosti odnosno o nepostojanju notorne činjenice u slučajevima u kojima bi, izvan navedenih slučajeva u kojima bi svoju odluku morao utemeljiti na strogim pravilima o tome, prosuđivao ima li opravdanih razloga da posumnja (često polazeći od stava o hipotetskoj konkluzivnosti navoda iz prigovora) da činjenica o kojoj je riječ ipak nije notorna, odnosno da ne postoji ili da ne postoji onako kako je to notorno.

Notornost bi zapravo već zbog svoje prirode pretpostavljala nespornost, odnosno opće suglasje o odgovarajućem svojstvu neke činjenice i o tome kakva je ona, pa bi zato u načelu osporavanje trebalo otkloniti samo ako bi bilo očito neutemeljeno. U suprotnom bi, dakle kad god bi, makar hipoteski, postojali indiciji za razumnu sumnju u to da neka činjenica nije notorna odnosno da nije onakva kako je to notorno, trebalo provesti odgovarajuće provjere, zapravo dopustiti utvrđivanje (u pravilu dokazivanjem) protivnog. Mjera provjere ovisila bi o razlozima zbog kojih je ona određena i o onome što bi se tijekom njezine provedbe sukcesivno utvrđivalo. Ako bi ocijenio da je rezultati do kojih bi postupno dolazio tijekom započete provjere ne opravdavaju, sud bi uvijek mogao odustati od njezine daljnje provedbe.

\subsection{Troškovi provjere}

Za troškove provjere je li neka činjenica notorna odnosno postoji li ona unatoč tome što se smatra da je notorno da postoji vrijede opća pravila o predujmljivanju sredstava za izvođenje dokazivanja (153.) te o snošenju troškova prema uspjehu u parnici (154.) odnosno po kriteriju krivnje ili slučaja (156.).

\subsection{Dokazivanje notornosti}

Dokazivati da je neka činjenica notorna bilo bi zapravo protivno prirodi notornosti. To bi, naime, značilo dokazivati sucu da je ona općepoznata iako on za nju ne zna ili ne zna onako kako bi trebao znati, odnosno da, iako za nju zna, ne zna da je notorna. Mogućnost takva dokazivanja bi, međutim, pretpostavljala određivanje pojma notornosti kao nečega za što znade određena kvalificirana većina ljudi određenih svojstava na određenom području, među koje bi se mogao, ali se ne bi morao nalaziti i sudac koji bi trebao odlučiti uzimajući takvo znanje o toj činjenici kao relevantno utvrđenje o njezinu postojanju (mimosudska notornost; nametnuta notornost). Pritom bi sudac, zato što ne postoji "registar notornih činjenica", trebao izvoditi dokaze radi toga da bi se uvjerio da je činjenica za koju bi se tvrdilo da je takva zaista takva, 
dokaze koji bi ga trebali uvjeriti da za nju zna i kako za nju zna potrebna kritična masa ljudi, dokaze koje bi ocjenjivao - već prema njihovoj prirodi - po slobodnoj ili legalnoj ocjeni. Ako bi se dokazalo takvo svojstvo neke činjenice na razini sigurnosti, sudac bi već samo zbog toga morao uzeti da ona postoji (presumpcija o postojanju činjenice na temelju utvrđenja o njezinoj notornosti). Zato on ne bi smio izvoditi dokaze radi njezina utvrđenja kao što bi to bio dužan učiniti kad ne bi bilo utvrđeno da je notorno njezino postojanje - svakako, osim ako ne bi sam posumnjao u to da ona, unatoč takvoj svojoj notornosti, ne postoji ili da je drukčije nego što je notorno. Naime, kao što je sudac ex officio dužan prigodom donošenja svoje odluke uzeti u obzir općepoznate činjenice (v. infra ad 7.), tako bi trebao biti ovlašten po službenoj dužnosti provjeravati svoje sumnje postoje li valjani razlozi za to da uzme da neka činjenica za koju je općepoznato da postoji ipak nije notorna ili da ne postoji onako kako je to notorno. Bilo bi dovoljno da njegova takva provjera opravda naznačene sumnje, pa da dopusti utvrđivanje neke činjenice drugim dostupnim metodama njezina utvrđivanja.

\subsection{Oficijelnost}

Iz odredbe prema kojoj općepoznate činjenice ne treba dokazivati (221/4.) može se izvesti zaključak da se smatra da one postoje ili da ne postoje onako kako je općepoznato (v. supra ad II.2.2.3.), ali ne i da sud o tom znanju treba voditi računa po službenoj dužnosti pa ih uzeti u obzir i kad se stranke na njih nisu pozvale. Na to da je sud te činjenice ipak dužan uzeti u obzir ex officio upućuju, međutim, argumento a cohaerentia, a completudine, pravila koja brane sudu da donese presudu zbog ogluhe i zbog izostanka kad iz općepoznatih okolnosti proizlazi da su tuženika spriječili opravdani razlozi da dâ odgovor na tužbu odnosno da dođe na ročište (331.b/1.4.; 332/1.5.), kao i pravila po kojima sud smije donijeti te presude (tek) ako, pored ostaloga, utvrdi da činjenice na kojima se temelji tužbeni zahtjev nisu u protivnosti s činjenicama koje su općepoznate (331.b/1.3., 332/1.4.). ${ }^{37}$ Tome u prilog, s istom argumentacijom, govori i odredba po kojoj sud smije odlučiti o prijedlogu za povrat u prijašnje stanje bez održavanja ročišta ako su činjenice na kojima se prijedlog temelji općepoznate (121/1.).

\subsection{Zabrana dokazivanja}

Odredbu prema kojoj općepoznate činjenice ne treba dokazivati (221/4.), valja zapravo protumačiti u smislu da sud te činjenice ne smije dokazivati sve dok je na zahtijevanoj razini uvjeren u takvo njihovo svojstvo i time postojanje (zabrana dokazivanja općepoznatih činjenica). Tek kad se ta razina uvjerenosti dovede u pitanje, sud je dužan dopustiti dokazivanje da nije riječ o notornoj činjenici, odnosno da ne postoji ono za što je notorno da postoji ili da ne postoji onako kako je notorno.

37 U tom smislu i TRIVA-DIKA, GPPP, 180. 


\subsection{Obavještavanje stranaka i raspravljanje o notornosti}

Sud je dužan obavijestiti stranke o tome da neku činjenicu smatra notornom i da će je stoga prigodom donošenja svoje odluke bez dokazivanja (ili primjene neke druge metode utvrđivanja) uzeti u obzir po službenoj dužnosti te im omogućiti da se o tome izjasne, da o tome raspravljaju (arg. ex 7/3., 11., 219/2., 288.a/2.). Propust suda da strankama omogući da raspravljaju o njegovu stavu o postojanju neke notorne činjenice može imati začenje apsolutno bitne povrede odredaba parničnog postupka (7/3., 354/2.6.). Sud sa strankama, svakako, može raspravljati i o tome treba li neku činjenicu smatrati notornom, dakle i prije nego što o tome zauzme (ili očituje) svoj stav.

Suglasnost stranaka o tome da je neka činjenica notorna treba shvatiti kao priznanje te činjenice (221/1., 2.), osim ako i sam sud ne smatra da je riječ o takvoj činjenici. Takva suglasnost sama po sebi ne može spriječiti provjeru idu li stranke njezinim očitovanjem za tim da raspolažu pravima kojima ne mogu raspolagati (7/2., 221/2.), da, dakle, ostvare pravozaštitni rezultat koji bi bio protivan prisilnim propisima i javnom moralu (3/3.). Upravo bi stoga trebalo zauzeti stav da je nemoralno i stoga nedopušteno priznanjem neke činjenice za koju je općepoznato drukčije navoditi suca da na takvom priznanju utemelji svoju odluku. Tome u prilog govori i dužnost suca da ex officio uzme u obzir notorne činjenice, dakle neovisno o tome jesu li ih stranke iznijele i kakav su stav o njima zauzele. Nedopuštenost takvog priznanja očitovala bi se i u tome što bi ono bilo protivno dužnosti stranaka da govore istinu (9.).

\subsection{Pravne posljedice povrede pravila o notornosti}

Ako sud ne uzme u obzir neku pravno relevantnu činjenicu koja je općepoznata, odluka se može pobijati žalbom zbog nepotpuno utvrđenog činjeničnog stanja, a ako na nekoj činjenici koja nije općepoznata kao općepoznatoj utemelji svoju odluku, zbog pogrešnog utvrđenja toga stanja (353.2., 355.), osim u sporovima male vrijednosti u kojima žalba nije dopuštena zbog pogrešno i nepotpuno utvrđenog činjeničnog stanja (arg. ex 353., 354. i 467/1.).

Zabrana iznošenja meritorno relevatnih činjenica u žalbi (352/1.) ne odnosi se na općepoznate činjenice - tu propust suda da po službenoj dužnosti uzme u obzir takve činjenice može imati značenje relativno bitne povrede odredaba parničnog postupka (arg. ex 353.1., 354/1.). Zato bi žalitelj, ističući u žalbi neku novu činjenicu kao općepoznatu, zapravo dokazivao postojanje takve povrede. Zbog ove se povrede, kao uostalom i općenito zbog relativno bitnih povreda odredaba parničnog postupka žalba ne može podnijeti u sporovima male vrijednosti (arg. ex 353., 354. i 467/1.).

Ako bi prvostupanjski sud uzeo u obzir neku općepoznatu činjenicu iako strankama nije bilo omogućeno da se o njoj izjasne, počinio bi apsolutno bitnu povrede odredaba parničnog postupka nezakonitim uskraćivanjem strankama prava da raspravljaju pred sudom (7/3., 354/2.6.; v. i supra ad III.9.).

Drugostupanjski sud u povodu žalbe nije ovlašten po službenoj dužnosti voditi računa o općepoznatim činjenicama jer on tako ne pazi na pogrešno i nepotpuno 
utvrđeno činjenično stanje, a ni na relativno bitne povrede odredaba parničnog postupka (arg. ex 365/2.). Drugostupanjski bi sud, ipak, mogao ukinuti pobijanu presudu ako bi, uzimajući u obzir neku općepoznatu činjenicu, našao da je prvostupanjski sud protivno odredbama Zakona svoju odluku utemeljio na nedopuštenim raspolaganjima stranaka i time počinio apsolutno bitnu povredu odredaba parničnog postupka ( $\mathrm{arg}$. ex 354/2.4.). On bi, eventualno (što bi bilo vrlo "nategnuto"), mogao uzeti i da presuda ima nedostataka zbog kojih se ne može ispitati zato što prvostupanjski sud prigodom njezina donošenja nije uzeo u obzir neku notornu činjenicu (354/2.11.).

Presuda zbog ogluhe (331.b/1.3.) i presuda zbog izostanka (332/1.4.) mogu se pobijati i zato što je sud prigodom njihova donošenja propustio ocijeniti dovode li, između ostaloga, u pitanje osnovanost tužbenog zahtjeva ičinjenice koje su općepoznate (arg. ex 354/2.5.). Propuštanje prvostupanjskog suda da prigodom donošenja ovih presuda uzme u obzir i notorne činjenice bilo bi, međutim, sankcionirano kao jedna apsolutna povreda odredaba parničnog postupka. Propuštanje suda da prigodom donošenja navedenih presuda uzme u obzir općepoznate činjenice iz kojih bi proizlazilo da tuženik iz opravdanih razloga nije podnio odgovor na tužbu odnosno da je zbog takvih razloga propustio prvo ročište moglo bi također imati značenja jedne specifične apsolutno bitne povrede odredaba parničnog postupka (354/2.5.).

Stranka bi mogla tražiti ponavljanje postupka zbog činjenice koja je postojala kad ju je mogla iznijeti tijekom postupka prije pravomoćnosti, a koja je inače općepoznata, ako bi učinila barem vjerojatnim da bez svoje krivnje nije znala da ona, unatoč tom svom svojstvu, postoji, odnosno da je važna za rješenje spora (arg. ex 421/1.10.). ${ }^{38}$

\subsection{Odnos prema drugim metodama utvrđivanja činjenica}

Iako je sud dužan po službenoj dužnosti uzeti u obzir općepoznate činjenice prigodom donošenja svoje odluke, on neće smijeti uvijek tako postupiti. Naime, ako je neka činjenica utvrđena pravomoćnom sudskom odlukom drukčije nego što je to općepoznato, sud će u granicama u kojima se uz takvu presudu veže neoboriva predmnjeva o istinitosti njezina sadržaja (arg. ex: 12/1., 2.; 421/1. 8., 9.) morati poštovati tu presudu. U tom bi smislu notornost bila slabija od pravomoćnosti.

38 Suđeno je da okolnost da se u sporovima radi utvrđivanja očinstva već dulje izvodi dokaz tipizacijom tkiva nije općepoznata, zbog čega je, kad je tuženik, tražeći ponavljanje postupka, predložio taj dokaz, zauzet stav da je potrebno utvrditi kad je on saznao za mogućnost njegovog izvođenja (VSH: Gž-44/84 -PSP 27/145.). Iz navedenog stajališta, za koje bi se moglo reći da je «prevladano» razvitkom biomedicinskih znanosti do kojega je u međuvremenu došlo, proizlazilo bi, čini se, daljnje stajalište da se, da je ta činjenica bila općepoznata, zbog nje, neovisno o tome kad se za nju saznalo, ne bi moglo tražiti ponavljanje postupka. Uz notornost neke činjenice bi se uvijek vezalo znanje o činjenici. Treba, međutim, upozoriti na to da predlagatelj koji traži ponavljanje postupka treba dokazati da bez svoje krivnje neku činjenicu za koju je saznao prije pravomoćnosti nije upotrijebio u postupku prije toga (arg. ex 421/1.10, 422/2.) - ne bi bilo dovoljno samo to da je za nju znao. Naime, stranka bi mogla tek iz drugostupanjske presude ili presude revizijskog suda saznati da je neka općepoznata činjenica za koju je znala već tijekom prvostupanjskog postupka pravno relevantna, a da je nije iznijela tijekom prethodećeg postupka zato što ni ona, a ni prvostupanjski sud nisu smatrali da je takva. 
Pozivanjem na notornost moglo bi se, međutim, tvrditi da je nakon momenta na koji se odnosi pravomoćnost presude nastala činjenica čije je postojanje općepoznato, koja dezuvuira utvrđenje iz presude. U ovom bi drugom slučaju notornost imala prednost pred pravomoćnošću.

Notornost je općenito slabija od neoborivih predmnjeva: onda kada pravila o neoborivim predmnjevama upućuju na postojanje neke činjenice, sud mora uzeti da ona postoji iako je notorno drukčije.

Notornost je, međutim, jača od priznanja činjenica. Naime, iako je neka činjenica - izrijekom ili prešutno - priznata, sud neće biti vezan tim priznanjem ako je notorno drukčije, između ostaloga i stoga što bi bilo protivno javnom moralu siliti suca da uzme da postoji nešto oko čega su se stranke suglasile iako je općepoznato drukčije (arg. ex 221/1., 2.), odnosno zato što bi to bilo protivno dužnosti stranaka da govore istinu (9.) (v. i supra ad III.9.).

Notornost (u pravilu - v. supra) isključuje potrebu dokazivanja (221/4.); ona je jača od neiznošenja tvrdnji o činjenicama (arg. ex 7/2., 221/1., 221/4., 331.b, 332.), ali i od utvrđivanja činjenica primjenom pravila o oborivim predmnjevama (221/3., 221/4.).

\section{ZAKLJUČNE NAPOMENE}

Institut notornosti kao institut koji uređuje jednu od metoda utvrđivanja činjenica jest jedan od instituta prava utvrđivanja činjenica, prava koje, određujući kriterije za utvrđivanje činjenica kao elemenata niže premise logičkog silogizma presude, uređuje sadržajni, pravozaštitni aspekt njihova utvrđivanja ("pravozaštitno pravo utvrđivanja činjenica"), ali, propisujući i proceduru koja će se pritom primijeniti, i postupovnopravni aspekt toga utvrđivanja ("postupovno pravo utvrđivanja činjenica u užem smislu"). Naznačeno razlikovanje između dviju grana prava utvrđivanja činjenica u parničnom postupku primijenjeno na institut notornosti nije relevantno samo za razumijevanje pravne prirode pojedinih pravila koja uređuju taj institut, već i za određivanje razloga za pobijanje sudskih odluka zbog njihove povrede hoće li biti riječ o pogrešno i nepotpuno utvrđenom činjeničnom stanju ili o bitnim povredama odredaba parničnog postupka. Iako to razlikovanje u načelu može biti važno i za određivanje prava koje će biti mjerodavno za izbor te za određivanje sadržaja i značenja pravila koja se tiču pravozaštitnog odnosno proceduralnog aspekta utvrđivanja činjenica, za odgovor na pitanje hoće li to biti uvijek pravo suda ili, uz određene pretpostavke, i strano pravo, kao što je to slučaj kod pravnih predmnjeva i pravila o teretu dokazivanja, ono zbog specifičnosti pravila koja ga uređuju ne dolazi do izražaja u vezi s institutom notornosti - za njegovo je prosuđivanje uvijek mjerodavno pravo suda.

Za razumijevanje instituta notornosti osobito je važno razlikovanje između dvaju pravila koja određuju njegovu pravozaštitnu bit: razlikovanje između "negativnog pravila", koje je izrijekom utvrđeno u Zakonu i kojim se sud oslobađa, kojim se sudu "zabranjuje" da općepoznate činjenice dokazuje, i impliciranog "pozitivnog pravila" pravila koje sudu nalaže da o notornoj činjenici zaključi onako kako je to općepoznato 
(presumptivnost notornosti), pravila koje svojim postojanjem daje puni, pravi smisao institutu.

Primjena pravila o notornosti pretpostavlja sigurnost uvjerenja suda u takvo svojstvo određenih činjenica. Zato mora postojati mogućnost dokazivati da neka činjenica nije notorna i da je stoga treba utvrđivati primjenom drugih metoda utvrđivanja činjenica, u pravilu dokazivanjem, odnosno da ne postoji ono što je notorno ili da ne postoji onako kako je to notorno - kad god se pojavi opravdana sumnja u takva njezina svojstva. Postojanje takve mogućnosti zahtijeva relativnost ljudskog znanja pa stoga i svega onoga što se smatra općepoznatim. Ta je mogućnost osobito važna radi otklanjanja opasnosti koje "olaka" ili "programirana" ("nametnuta") primjena instituta implicira. Upravo se stoga čini razumnim restrinktivno određivati pojam notornosti i svakako ga uvjetovati i znanjem suca (članova vijeća) koji određenu činjenicu treba (trebaju) utvrditi: on (oni) moraju znati za određenu činjenicu zato što je notorna i onako kako je to notorno - ne smije im se moći dokazivati da je riječ o takvoj činjenici, znanje im se o takvu njezinu svojstvu ne smije moći nametati, osobito ne kao "pravno (politički, čudoredno, religijski itd.) utvrđeno" znanje ("apriorna" notornost).

\section{LITERATURA}

1. Dika, Mihajlo, O standardima utvrđenosti činjenica u parničnom postupku, Zbornik Pravnog fakulteta Sveučilišta u Rijeci, vol. 36, br. 1/2015., str. 1-70.

2. Dika, Mihajlo, Zakonske predmnjeve - prilog učenju o virtualnosti pravne stvarnosti, Zbornik Pravnog fakulteta Sveučilišta u Rijeci, vol. 35, br. 1/2014., str. 1-60.

3. Juhart, Jože, Civilno procesno pravo FLRJ, Univerzitetna založba, Ljubljana, 1961.

4. Poznić, Borivoje, Rakić-Vodinelić, Vesna, Građansko preocesno pravo, 15. izdanje, Savremena administracija, Beograd, 1999. i 17. izdanje, Pravni fakultet Univerziteta Union, Službeni glasnik, Beograd, 2015.

5. Triva, Siniša, Dika, Mihajlo, Građansko parnično procesno pravo, Narodne novine, Zagreb, 2004.

6. Rechberger, Walter H., Simotta, Daphne A., Zivilprozessrecht, Erkenntnisverfahren, 7. izd., Manz Verlag, Wien, 2009.

7. Fasching, Hans W., Kommentar zu den Zivilprozeßgesetzen, Band 3, 2. izd., Manz Verlag, Wien, 2004.

8. Rosenberg, Leo, Schwab, Karl Heinz, Gottwald, Peter, Zivilprozessrecht, Verlag C.H. Beck, München, 2010.

9. Fasching, Hans W., Lehrbuch des österreichischen Zivilprozeßrechts, Manz Verlag, Wien,1990.

10. Zakon o parničnom postupku, NN, br. 53/91., 91/92., 112/99., 129/00., 88/01., 117/03., 88/05., 2/07., 96/08., 84/08., 123/08., 57/11., 25/13., 89/14. 
Summary

\section{GENERALLY KNOWN FACTS IN LITIGATION}

This paper deals with generally known facts in litigation with review on some viewpoints accepted in Austrian, German and Croatian jurisprudence and legal practice on this topic. First starting theoretical viewpoint in this research is that the establishment of facts by rules on generally known facts is one of methods for establishment of facts. Regular method for establishment of facts is proving, but it has subordinate nature. Other methods for establishment of facts are application of rules on recognition, on legal presumptions and on burden of proof. Second starting theoretical viewpoint is that the law on establishment of facts has dual legal nature: it has legal protective and procedural aspect. Author discusses on various problems with regard to notion, legal basis and characteristics of generally known facts and on implementation of rules on their establishment in litigation.

Keywords: generally known facts, establishment of facts, litigation.

\section{Zusammenfassung}

\section{OFFENKUNDIGE TATSACHEN IM ZIVILPROZESS}

Die vorliegende Arbeit setzt sich mit offenkundigen Tatsachen im kroatischen Zivilprozessrecht auseinander. Der Fokus wird auf die österreichische, deutsche und kroatische Jurisprudenz und Rechtsprechung gelegt. Es wird theoretisiert, dass das Feststellen von Tatsachen nach den Regeln für offenkundige Tatsachen eine Methode der Tatsachenfeststellung darstellt. Dabei ist die Beweisaufnahme die gewöhnliche, obgleich subsidäre, Methode für die Tatsachenfeststellung. $\mathrm{Zu}$ anderen Methoden der Tatsachenfeststellung zählt die Anwendung von Tatsachenanerkenntnis-, Voraussetzungen- und Beweislastbestimmungen. Anschließend dazu wird schlussfolgert, dass das Recht der Tatsachenfeststellung gleichzeitig schutzrechtliche, wie auch verfahrensrechtliche Aspekte umfasst. Darüberhinaus untersucht der Autor die Rechtsgrundlage der offenkundigen Tatsachen und die Anwendung der entsprechenden Bestimmungen im Rahmen des Zivilprozesses.

Schlüsselwörter: offenkundige Tatsachen, Feststellung von Tatsachen, Zivilprozess. 


\section{Riassunto}

\section{FATTI NOTORI NEL PROCESSO CIVILE}

Il presente lavoro tratta dei fatti notori nel processo civile, prestando attenzione ad alcuni orientamenti adottati a tale riguardo nella giurisprudenza e nella dottrina austriaca, tedesca ed i quella croata. Il fondamento teorico da cui si parte nell'indagine è il convincimento che l'accertamento dei fatti in ragione dell'applicazione delle regole sui fatti notori rappresenti uno dei modi di accertamento dei fatti. La modalità ordinaria per accertare i fatti è la prova; tuttavia essa ha natura subordinata. Altri metodi di accertamento dei fatti si fondano sull'accertamento dei fatti, sulle presunzioni legali e sull'onere probatorio. Un secondo fondamento teorico da cui si parte è che il diritto all'accertamento dei fatti che disciplina tutti i metodi menzionati abbia una doppia natura giuridica, la quale si esplicita nel suo aspetto di tutela legale ed in quello processualistico. L'autore tratta di varie questioni concernenti la nozione, il fondamento giuridico e le caratteristiche dei fatti notori, come pure delle regole volte all'accertamento dei medesimi nel processo civile.

Parole chiave: fatti notori, accertamento dei fatti, processo civile. 
